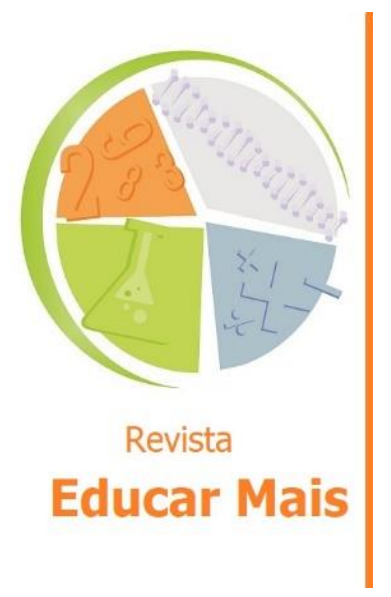

\title{
Travessias e (des)encontros: práticas pedagógicas remotas na educação infantil em Rolim de Moura/RO
}

\author{
Crossings and (dis)meetings: remote pedagogical practices in early \\ childhood education in Rolim of Moura/RO
}

\section{Cruces y (des)encuentros: prácticas pedagógicas a distancia en la educación infancia en el Rolim de Moura/RO}

Juverlande Nogueira Pintoㄹ; Edre Almeida Corrêa²; Bianca Santos Chisté3; Vanderléia de Lourdes Rodrigues Lopes de Oliveira ${ }^{4}$

\section{RESUMO}

Em 2020, devido a Pandemia do vírus COVID-19 vários setores foram atingidos e na Educação surgiram desafios emergentes às práticas de professoras. Neste artigo, o objetivo é compreender as práticas pedagógicas desenvolvidas em tempo de Pandemia, por professoras da Educação Infantil no município de Rolim de Moura/RO. Participaram da pesquisa 10 (dez) professoras que atuam em instituições distintas. Para produção de dados foram enviados dois questionários, um com perguntas abertas e fechadas e outro com roteiro. $O$ artigo se apoia nas ideias de Leite (2011), Clareto e Nascimento (2012), Oliveira (2018), Borba e Penteado (2001), Gil (2002), entre outros. Refletimos sobre o currículo da Educação Infantil; as tecnologias no fazer e agir das professoras e crianças; efeitos da Pandemia, que no alinhavo dos relatos das professoras, possibilitou pensar em como seria um currículo acontecimento no distanciamento entre os corpos e sobre as aulas longe do movimento das crianças e das professoras.

Palavras-chave: Educação Infantil; Práticas Pedagógicas; Pandemia; Tecnologias.

\begin{abstract}
In 2020, with the pandemic of the COVID-19 virus, several sectors were affected and in Education emerged challenges to the practices of teachers. In this article, the objective is to understand the pedagogical practices developed during Pandemic times, by teachers of Early Childhood Education in the municipality of Rolim de Moura/RO. Ten (10) teachers who work in different institutions participated in the research. Two questionnaires were sent for data production, one with open and closed questions and the other with a script. The article is based on the ideas of Leite (2011), Clareto and Nascimento (2012), Oliveira (2018), Borba and Penteado (2001), Gil (2002), among others. We reflected on the Early Childhood Education curriculum; technologies in the making and acting of teachers and children; effects of Pandemic, which in the making of the teachers' reports, made it possible to think about what a curriculum would look like in the distance between bodies and about classes away from the movement of children and teachers.
\end{abstract}

Keywords: Early Childhood Education; Pedagogical practices; Pandemic; Technologies.

\footnotetext{
${ }^{1}$ Mestranda em Educação Matemática pela Universidade Federal de Rondônia (UNIR), Campus Ji-Paraná/RO. Coordenadora de Cultura Escolar na Secretaria Municipal de Educação de Ji-Paraná/RO - Brasil.

2 Mestranda em Educação Matemática pela Universidade Federal de Rondônia (UNIR), Campus Ji-Paraná/RO Brasil. Tradutora/Intérprete de Língua Brasileira de Sinais (LIBRAS).

${ }^{3}$ Doutora e Pós-Doutoranda em Educação Matemática e docente da Universidade Federal de Rondônia (UNIR) - Campus de Rolim de Moura/RO - Brasil. Integra os grupos de pesquisa IM@GO (UNESP/Rio Claro), GEPPEA (Rolim de Moura/UNIR) e Cronópi@s (UNESP/Rio Claro).

${ }^{4}$ Mestranda em Ensino de Ciências da Natureza na Universidade Federal de Rondônia (UNIR) - Campus de Rolim de Moura. Professora de Educação Infantil na EMEI Balão Mágico, Rolim de Moura/RO - Brasil.
} 


\section{RESUMEN}

En 2020, con la pandemia del virus COVID-19, varios sectores se vieron afectados y en Educación surgieron desafíos a las prácticas de los docentes. En este artículo, el objetivo es comprender las prácticas pedagógicas desarrolladas durante la época de la Pandemia, por los profesores de Educación Infantil del municipio de Rolim de Moura/RO. Participaron de la investigación diez (10) docentes que laboran en diferentes instituciones. Para la producción de datos se enviaron dos cuestionarios, uno con preguntas abiertas y cerradas y otro con guión. EI artículo se basa en las ideas de Leite (2011), Clareto y Nascimento (2012), Oliveira (2018), Borba y Penteado (2001), Gil (2002), entre otros. Reflexionamos sobre el plan de estudios de Educación Infantil; tecnologías en la creación y actuación de maestros y niños; efectos de la pandemia, que en la elaboración de los informes de los docentes, permitió pensar en cómo sería un currículo en la distancia entre los cuerpos y en las clases alejadas del movimiento de niños y maestros.

Palabras clave: Educación en la primera infancia; Prácticas pedagógicas; Pandemia; Tecnologías.

\section{INTRODUÇÃO}

Em 2020 acompanhamos a Pandemia que se alastrou no mundo chegando até o continente americano. No Brasil, quando surgiu o primeiro caso de infectado por vírus COVID-19, foi publicada no Diário Oficial da União dia 07 de fevereiro de 2020, a LEI No 13.979 de 06 de fevereiro de 2020, que estabelece as Medidas para enfrentamento da emergência de saúde pública de importância internacional decorrente do Coronavírus responsável pelo surto de 2019. No dia 20 de março de 2020, o Diário Oficial da União publicou em sua Edição: 55-C, Seção: 1 a ocorrência do estado de calamidade pública.

No início de março a população rondoniense foi atravessada pela pandemia do COVID-19, isso afetou o dia a dia dos rondonienses. O Governo do Estado de Rondônia, estado localizado no norte brasileiro e integrante da Amazônia Legal, publicou o primeiro Decreto Estadual No 24.871, que decretava a calamidade pública, acompanhando o decreto da União, que em seu Artigo 50 instituiu a suspensão pelo prazo de 15 (quinze) dias, podendo ser prorrogada por iguais períodos, as atividades educacionais em todas as instituições das redes de ensino pública e privada. Essa medida se constituiu como única forma de enfrentamento ao contágio e evitar colapso da saúde pública.

Em 26 de abril, o Decreto Estadual № 24.979 em seu Artigo $4^{\circ}$ sobre as atividades educacionais, dispôs que:

$\S 2^{\circ}$ Os municípios poderão optar pelo retorno das atividades educacionais a partir de 04 de maio de 2020, observando as recomendações do Ministério da Saúde, os Protocolos clínicos do Coronavírus - COVID-19 e as diretrizes estabelecidas no Plano Nacional de contingência para Infecção Humana do Coronavírus - COVID-19.

Com o objetivo de orientar os estados e municípios, o Conselho Nacional de Educação (CNE) aprovou o parecer elaborado com a colaboração do Ministério da Educação (MEC), em 28 de abril, diretrizes para orientar escolas da Educação Básica e instituições de ensino superior durante a Pandemia do coronavírus. Para a Educação Infantil a orientação foi a seguinte:

[...] para creche e pré-escola é que os gestores busquem uma aproximação virtual dos professores com as famílias, de modo a estreitar vínculos e fazer sugestões de atividades às crianças e aos pais e responsáveis. As soluções propostas pelas escolas e redes de ensino devem considerar que as crianças pequenas aprendem e se desenvolvem brincando prioritariamente (PORTAL MEC, 2020, s.p.). 
Assim, iniciou uma prática pedagógica que ficou conhecida como "ensino remoto". Em 30 de Julho de 2020, o Decreto Estadual No 25.263, altera e acresce dispositivos do Decreto Estadual № 25.049, de 14 de maio de 2020, e institui que em seu Artigo 40, que:

As atividades educacionais presenciais regulares na rede estadual, municipal e privada ficam suspensas até o dia $1^{\circ}$ de setembro do ano corrente, aplicando-se em todos os municípios, ressalvada a existência de estudos apontando à viabilidade de retomada em prazo anterior ou por decisão local dos seus respectivos prefeitos.

Em um contexto nunca antes vivido, a Educação foi direcionada de decreto em decreto, na expectativa de possível retorno, porém a cada dia essa possibilidade se distanciava da realidade diante do aumento de contágio e morte entre a população rondoniense. No dia 31 de agosto de 2020, o Decreto Estadual No 25.348 prorrogou a suspensão as atividades educacionais presenciais regulares na rede estadual, municipal e privada até o dia 3 de novembro do ano corrente. Recentemente o CNE autorizou o ensino remoto até 31 de dezembro de 2021.

Neste contexto, a Educação Infantil vem desenvolvendo atividades remotas com as crianças, que assim como toda a população mundial vive à espera de uma vacina que possa permitir a humanidade voltar a interagir entre si.

O distanciamento social e a paralisação das atividades educacionais presenciais, que a priori pareciam serem breves, mostraram-se sem prazo para encerrar. Todos os dias os noticiários e a mídia apresentavam um contexto de perdas de população, sem ter outras formas de evitar, a não ser com as medidas de segurança e distanciamento entre as pessoas.

Neste cenário, o objetivo deste artigo é compreender as práticas pedagógicas desenvolvidas, em tempo de Pandemia, por professoras da Educação Infantil no município de Rolim de Moura/RO. Através de debate acerca dos atravessamentos, afetações, (des)encontros, provocados pela Pandemia do COVID19 nas práticas pedagógicas na Educação Infantil que passa também a vivenciar o (des)encontro dos corpos, das vivências, dos encontros com outras formas de fazer educação; e os atravessamentos das Tecnologias Digitais nesse fazer e agir das professoras e das crianças.

\section{TRAVESSIAS NA EDUCAÇÃO INFANTIL - CURRÍCULO ACONTECIMENTO}

"O delírio do verbo estava no começo, lá onde a criança diz: Eu escuto a cor dos passarinhos. A criança não sabe que o verbo escutar não funciona para cor, mas para som."

Manoel de Barros

A epígrafe de Manoel de Barros nos convoca, provoca, sensibiliza... Um sujeito criança que escuta " $a$ cor dos passarinhos", criança que habita o espaço Educação Infantil, que vive no acontecimento, na experiência de descobrir o mundo e a si. Isso nos coloca o pensamento em movimento para algumas indagações: O que pode uma Educação Infantil em tempo de isolamento social? O que pode as tecnologias digitais nas práticas de professores e professoras da Educação Infantil? Quais são as afetações das tecnologias digitais nas práticas pedagógicas? Que relações são estabelecidas em Educação de corpos ausentes, de isolamento com um currículo? 
Neste sentido, iremos abordar acerca dessas questões, que se inicia com o diálogo com o currículo da Educação Infantil, o qual Oliveira $(2010$, p.3) pressupõe que o currículo é a apresentação de:

[...] princípios básicos orientadores de um trabalho pedagógico comprometido com a qualidade e a efetivação de oportunidades de desenvolvimento para todas as crianças. Ainda segundo a autora o currículo põe o foco na ação mediadora da instituição de Educação Infantil como articuladora das experiências e saberes das crianças os conhecimentos que circulam na cultura mais ampla e que despertam o interesse das crianças $[\ldots]$.

Clareto e Nascimento (2012, p.317) falam de um "currículo-invenção como um processo inventivo de produção de abertura, de processo de atualização de potencialidades [...]". Os autores apontam para um currículo que abre espaço para os saberes, inventividades, potenciais, descobertas, criações, devires, aberto às crianças. As Diretrizes Curriculares Nacionais para a Educação Básica (DCN), em consonância com a Resolução No 05 de 17 de dezembro de 2009, define o currículo para a Educação Infantil,

[...] como um conjunto de práticas que buscam articular as experiências e os saberes das crianças com os conhecimentos que fazem parte do patrimônio cultural, artístico, científico e tecnológico. Tais práticas são efetivadas por meio de relações sociais que as crianças desde bem pequenas estabelecem com os professores e as outras crianças, e afetam a construção de suas identidades (BRASIL, 2013, p.86).

As práticas pedagógicas na Educação Infantil seguem uma organização curricular bem específica para contemplar o modo próprio de as crianças aprenderem e se desenvolverem. Segundo as DCNs a criança é:

Sujeito histórico e de direitos que se desenvolve nas interações, relações e práticas cotidianas a ela disponibilizadas e por ela estabelecidas com adultos e crianças de diferentes idades nos grupos e contextos culturais nos quais se insere. Nessas condições ela faz amizades, brinca com água ou terra, faz-de-conta, deseja, aprende, observa, conversa, experimenta, questiona, constrói sentidos sobre o mundo e suas identidades pessoal e coletiva, produzindo cultura (BRASIL, 2013, p. 86).

Assim, observamos algumas convergências entre as argumentações de (OLIVEIRA, 2010) e (CLARETO; NASCIMENTO, 2012) com relação ao currículo normatizador para as práticas com crianças, que se faz como acontecimento nas mãos das crianças. Recentemente, outras orientações curriculares emergiram, uma organização que tinham como eixos estruturantes: interações e brincadeira, afirmada pela Resolução No 05, com a homologação da Base Nacional Comum Curricular (BNCC) em 20 de dezembro de 2017.

A Educação Infantil passa a se organizar também com seis Direitos de aprendizagem e desenvolvimento: brincar, conviver, explorar, expressar-se, conhecer-se e participar; bem como, cinco Campos de experiências: Corpo gestos e movimentos; Escuta, fala, pensamento e imaginação; Traços, sons, cores e formas; $\mathrm{O}$ eu, o outro, e o nós e Espaços, tempos, quantidades, relações e transformações.

Nessa direção, Oliveira (2018) aponta que o currículo por campos de experiências propõe a condução do trabalho pedagógico com práticas abertas às iniciativas, desejos e formas de agir das crianças na Educação Infantil. São considerados "um arranjo curricular que acolhe as situações e as experiências concretas da vida cotidiana das crianças e seus saberes, entrelaçando-os aos conhecimentos que fazem parte do patrimônio cultural" (BRASIL, 2017, p.40). 
Um currículo acontecimento, que acontece nas experiências das crianças e como são atravessadas por elas, Larrosa (2002) contribui afirmando que a "experiência é o que nos passa, o que nos acontece, o que nos toca.". Neste sentido, as práticas pedagógicas na Educação Infantil, se organizam no acontecimento de experiências cotidianas a partir dos interesses das crianças, práticas que são movimentadas pelas crianças nas interações, brincadeiras, relações, investigações, convivências que acontecem na vida social das crianças no espaço institucional.

Surge então as provocações ou indagações: Como a Pandemia do COVID-19 está atravessando as práticas pedagógicas das professoras com um currículo organizado por campos de experiências? Como professoras de Rolim de Moura estão efetivando seu currículo nas práticas pedagógicas?

\subsection{Currículo da Educação Infantil}

Após a homologação da BNCC, o estado de Rondônia construiu em Regime de colaboração com o MEC e municípios, o Referencial Curricular de Rondônia para a Educação Infantil, conforme a Portaria MEC No 331, de 5 de abril de 2018, sendo o primeiro documento orientador do estado para essa etapa de ensino. O município de Rolim de Moura iniciou um processo de implementação curricular, fazendo parte do movimento mediado pela equipe estadual do Programa de apoio à Implementação Curricular da Base Nacional Comum Curricular (ProBNCC). Assim, o município construiu seu Referencial Curricular Municipal, a partir do Referencial Curricular de Rondônia para a Educação Infantil à luz da BNCC.

O Referencial Curricular serve para orientar as práticas pedagógicas, levando em consideração as dez competências que atravessa toda a Educação Básica, consistindo na por meio de conhecimento, atitudes, competências, valores e habilidades. Oportunizar vivências e experiências no dia a dia escolar para que possam desenvolver as competências previstas.

Pensando no desenvolvimento global da criança, o currículo do município de Rolim de Moura parte do pressuposto na BNCC e na Diretrizes Curriculares Nacionais para a Educação Infantil (DCNEIs), tendo em vista os eixos estruturantes da práticas pedagógicas que são as interações e brincadeira, onde as crianças a partir das interações com os adultos e com seus pares, objetos, diálogos, jogos, música, entre outros, norteados pelas brincadeiras aprende, e se desenvolvem através da socialização com o meio cultural, social e físico. Dentro desses eixos se possibilita a troca de conhecimento e experiências.

Também fazem parte as competências gerais da Educação Básica: Conhecimento; Pensamento científico, crítico e criativo; Repertório cultural; Comunicação; Cultura digital; trabalho e projeto de vida; Argumentação; Autoconhecimento e autocuidado; Empatia, cooperação e responsabilidade e Cidadania. Pensando na formação integral e nos interesses e necessidades das Crianças.

Os Direitos de aprendizagem e desenvolvimento apresentam conformidade com os Campos de experiência: $\mathrm{O}$ eu o outro e o nós, que possibilita o autoconhecimento, a construção de relações baseadas no respeito, cooperativas, democráticas e desenvolver a consciência cidadã; Corpo gestos e movimentos, que leva a criança a se movimentar e conhecer o seu próprio corpo, interagindo com objetos, jogos, brincadeiras, danças e dramatizações; Traços sons cores e formas, campo este que possibilita às crianças experiências voltadas a expressividade, âmbito das artes visuais, da música, diálogo com a dança teatro e literatura; Escuta fala pensamento e imaginação que vê a criança como ser comunicativo, participativo de situações cotidianas com as pessoas com as quais interagem; Espaços, tempos, quantidades, relações e transformações, onde a criança desde cedo vivem em 
espaços e tempos de diferentes dimensões em um mundo constituído de fenômenos naturais e socioculturais.

Os Campos de experiências explicitam as vivências de aprendizagem oportunizadas às crianças, organizadas, projetadas e pensadas pelos docentes e pela comunidade escolar. O currículo demonstra dentro de sua capacidade, a autonomia de realizar atividades convencionais levando em conta os diferentes ritmos de aprendizagem da criança, e contribuindo com o bem estar do grupo e na sua realização como ser cultural, histórico e social.

Assim o currículo para a primeira infância no município de Rolim de Moura traz os direitos e os deveres entrelaçados envolvendo a comunidade escolar, as famílias, as crianças, as instituições e o educador que tem o papel de oportunizar, mediar e organizar as experiências das crianças. De acordo com a BNCC,

Parte do trabalho do educador é refletir, selecionar, organizar, planejar, mediar e monitorar o conjunto das práticas interações, garantindo a pluralidade de situações que promovam o desenvolvimento pleno das crianças (BRASIL, 2017, p.39).

Assim, nesse período atípico as professoras da Educação Infantil estão se reinventando para oferecer às crianças uma Educação de qualidade através das aulas remotas, contemplando os direitos de aprendizagem da criança.

O currículo da Educação Infantil traz também a importância do cuidar e do educar que são aspectos indissociáveis da ação pedagógica de acordo com cada faixa etária, que está dividida em: bebês de 0 a 1 ano e 6 meses, crianças bem pequenas de 1 ano e 7 meses a 3 anos e 11 meses, crianças pequenas de 4 anos a 5 anos e 11 meses; campo de experiência e objetivos de aprendizagem e desenvolvimento. A matriz curricular da Educação Infantil foi feita de acordo com as DCNEI, BNCC e Referencial Curricular do Estado de Rondônia (RCRO).

\section{AS TECNOLOGIAS DIGITAIS NO FAZER E AGIR DAS PROFESSORAS E DAS CRIANÇAS}

As Tecnologias Digitais em tempos de Pandemia têm amenizado a distância entre os corpos para aqueles que possuem o acesso a Internet e os equipamentos (celular, notebook, computador de mesa, tablet, entre outros), mas os (des)encontros ainda acontecem, pois, esses recursos tecnológicos ainda não são acessíveis a todos os brasileiros. O termo Tecnologia Digital é definida no glossário Glossário CEALE: termos de Alfabetização, Leitura e Escrita para educadores, da UFMG - Universidade Federal de Minas Gerais, como:

um conjunto de tecnologias que permite, principalmente, a transformação de qualquer linguagem ou dado em números, isto é, em zeros e uns (0 e 1). Uma imagem, um som, um texto, ou a convergência de todos eles, que aparecem para nós na forma final da tela de um dispositivo digital na linguagem que conhecemos (imagem fixa ou em movimento, som, texto verbal), são traduzidos em números, que são lidos por dispositivos variados, que podemos chamar, genericamente, de computadores. Assim, a estrutura que está dando suporte a esta linguagem está no interior dos aparelhos e é resultado de programações que não vemos. Nesse sentido, tablets e celulares são microcomputadores" (RIBEIRO, 2014, s.p.).

Para Bacich, Tanzi Neto \& Trevisani, (2015, p.48) "a interação das tecnologias digitais na Educação precisa ser feita de modo criativo e crítico, buscando desenvolver a autonomia e a reflexão dos envolvidos, para que eles não sejam apenas receptores de informações". 
Em alguns casos os estudantes que possuem algum aparelho celular na residência, ainda sim podem enfrentar dificuldades se o equipamento for dos pais/responsáveis e o uso ocorrer apenas no período noturno; ou quando têm mais de um estudante na residência que também necessita do acesso; ou a falta de acesso à Internet (banda larga móvel ou fixa) nomeada popularmente como "Dados Móveis" ou "Wiff".

Segundo Borba e Penteado (2001), a informática não tem a função de substituir ou complementar os seres humanos, mas de contribuir para a organização do pensamento. Isto é, "a interação das tecnologias digitais na Educação precisa ser feita de modo criativo e crítico, buscando desenvolver a autonomia e a reflexão dos envolvidos, para que eles não sejam apenas receptores de informações" (BACICH, TANZI NETO \& TREVISANI, 2015, p.48).

Isso demanda a capacitação sobre as funcionalidades desses recursos, entretanto na prática esse aprendizado acontece por meio das ações de tentativas e erros até conseguirem ou desistir do uso. 0 planejamento das propostas didáticas é um processo de autoconhecimento e desafios que englobam os seguintes pilares: "aprender a aprender", o "aprender a fazer", o "aprender a ser" e o "aprender a conviver", defendidos por Delors et al. (1996).

Assim, o acesso à tecnologia na educação não se resume apenas informatizar os ambientes escolares, mas também aos recursos que contribuam no processo de ensino e aprendizagem. Alguns registros das professoras serão discutidos nos tópicos do texto.

\section{OS CAMINHOS PARA COMPREENDER AS TRAVESSIAS, AFETAÇÕES E (DES)ENCONTROS}

A metodologia de pesquisa apresenta uma natureza qualitativa que "aprofunda-se no mundo dos significados das ações e relações humanas [...]" (MINAYO, 2002). Ao adotar a concepção qualitativa para realizar este estudo foi decisiva a natureza do objeto a ser analisado: práticas pedagógicas desenvolvidas remotamente na Educação Infantil.

Para produção de dados foram realizadas duas etapas, utilizou-se como instrumento de pesquisa tanto na primeira etapa quanto na segunda os questionários definido por Gil (2008, p. 128) como "a técnica de investigação composta por um conjunto de questões que são submetidas a pessoas com o propósito de obter informações sobre conhecimentos, crenças, sentimentos, valores, interesses, expectativas, aspirações, temores, comportamento presente ou passado etc".

Na primeira etapa, via formulário Google, solicitamos às professoras que respondessem o questionário com perguntas objetivas e discursivas (perguntas fechadas e abertas), para conhecermos melhor as professoras e os recursos tecnológicos utilizados por elas. Na segunda etapa, sentimos a necessidade de compreender as vivências profissionais relatadas por elas. Por isso, enviamos um roteiro com questões, que elas responderam por áudios e escritas via WhatsApp; depois as respostas foram transcritas pelas pesquisadoras.

Participaram dessa pesquisa 10 (dez) professoras, englobando todas as instituições públicas que atendem a Educação Infantil, no município de Rolim de Moura/RO, sendo: 02 (duas) escolas do campo; 01 (uma) do distrito de Nova Estrela e (quatro) escolas da área urbana. 
Após a transcrição e observação da produção de dados, buscamos traçar um mapeamento dos relatos das professoras entre pontos comuns e divergentes, o que possibilitou a organização de categorias.

A particularidade de cada relato foi importante para compreendermos um pouco deste cenário vivenciado por elas. Para isso, nos apoiaremos em Larrosa (2002); Oliveira (2010); Clareto e Nascimento (2012), entre outros e nos documentos normativos da Educação Infantil.

\section{ALINHAVOS ENTRE RELATOS DAS PROFESSORAS, EDUCAÇÃO INFANTIL, PANDEMIA E TECNOLOGIAS DE INFORMAÇÃO, COMUNICAÇÃO E DIGITAL}

As falas, escritas e foto os registros das professoras iam se juntando na segunda fase da pesquisa, compondo a imagem do dia a dia da Educação Infantil com travessias, afetações, (des)encontros com as Tecnologias de Informação, Comunicação e Digital (TIDICs) e a Pandemia. "O processo de análise e interpretação é fundamentalmente iterativo, pois o pesquisador elabora pouco a pouco uma explicação lógica do fenômeno ou da situação estudados, examinando as unidades de sentido, as interrelações entre essas unidades e entre as categorias em que elas se encontram reunidas" (GIL, 2002, p.90).

Os dados obtidos refletem as experiências vivenciadas por elas, os momentos em que tiveram que se reinventar diante das adversidades vividas e a coragem. Segundo Larrosa (2002, p.2) "as palavras produzem sentido, criam realidades e, às vezes, funcionam como potentes mecanismos de subjetivação". Torna-se visíveis os atravessamentos, os encontros e (des)encontros das professoras.

Ao iniciarmos o questionário, buscamos conhecer melhor as professoras participantes, por isso o primeiro passo foi saber a quanto tempo elas trabalham na Educação Infantil. Das 11 participantes: 03 (três) delas estão há seis anos; 01 (uma) há onze ano; 01 (uma) há nove anos; 01 (uma) há oito anos; 01 (uma) há cinco anos e uma professora está em seu primeiro ano de experiência nessa etapa de ensino. O próximo passo foi saber com qual faixa etária de crianças elas trabalhavam: 08(oito) responderam que trabalhavam com crianças de 04 anos a 05 anos e 11 meses (pré-escola); 02 (duas) professoras com crianças de 01 ano e 07 meses a 03 anos e 11 meses (creche). Ao descreverem sobre si, fizeram as seguintes descrições:

Teka: Sou uma pessoa que gosta de aprender em todas as oportunidades.

Liz: Professora de Educação Infantil

Luna: Professora que está sentindo falta da sala de aula...

Bia: Sou professora de Educação Infantil II, mas minha formação é em Educação Especial, especialista em AEE. Já são trinta anos de carreira e ainda continuo apaixonada pelo exercício do magistério.

Flor: Professora na Educação Infantil

Bela: Uma pessoa sonhadora que acredita na Educação.

Sol: Sou a (Sol) professora na Educação Infantil uma pessoa simples, humilde e que ama a educação em especial Educação Infantil.

Lua: Professora que ama trabalhar com Educação Infantil 
Mel: Sou uma pessoa muito sincera, amo o que faço, gosto das coisas certas e sempre tento dar o meu melhor em tudo.

Isis: Sou a (Isis), mãe de duas filhas lindas, esposa e professora de Educação Infantil.

Além das descrições como Professora da Educação Infantil, houve uma reflexão sobre o tempo, Bia fala de sua formação e lembra com nostalgia: [...] já são trinta anos de carreira e ainda continuo apaixonada pelo magistério; a descrição de Bia nos remete às palavras de Leite $(2011$, p.106) sobre o tempo: "[...] somos povoados por três ideias distintas de tempo: uma como algo circular, outra como linear, e o tempo como evento, acontecimento, experiência. As palavras de Bia apresentam uma relação com o tempo linear sobre os anos de profissão, mas também como acontecimento e experiência profissional".

Teve outras reflexões que também ultrapassaram a sala de aula, como de Isis e Sol, recentemente: Sou a (nome) mãe de duas filhas lindas, esposa e professora de Educação Infantil; Sou (nome) professora na Educação Infantil uma pessoa simples, humilde e que ama a educação em especial Educação Infantil.

Após a leitura e a observação dos relatos e registros referente às demais questões da pesquisa e respondidas pelas professoras, mapeamos, separando-as nas seguintes categoria: A utilização de recursos tecnológicos antes da Pandemia; Dificuldades e desafios em tempo de Pandemia; Planejamento das atividades; Recursos das tecnologias de informação, comunicação e digital utilizados no desenvolvimento das atividades; Como as professoras veem a utilização da tecnologia na Educação Infantil e Acompanhamento das atividades.

\section{- A utilização de recursos tecnológicos antes da Pandemia}

Nos relatos das professoras foi observado que utilizavam os recursos tecnológicos antes da Pandemia, principalmente com o planejamento e desenvolvimento de pesquisas, como observa-se as falas:

Teka: Normalmente em sala de aula usávamos vídeos, slides com imagens, apresentados para as crianças através de data show, notebook, caixa de som, etc. Equipamentos em sua maioria da própria escola, realizados semanalmente, porém em caráter complementar dependendo do tema trabalhado.

Flor: Sim, três vezes por semana, baixava vídeo sobre o tema da aula e passava para o dvd e apresentava na sala de aula.

Luna: Utilizava computador, notebook, celular em torno de duas a três vezes na semana.

Mel: Sim. Utilizava o celular via Bluetooth para ensinar musiquinha e passar vídeos educativos para as crianças e também utilizava para pesquisar algo diferenciado para melhor atender a realidade de meus alunos.

Sol: Para o planejamento usava. Mas para desenvolver as aulas em sala não utilizava.

Lua: Uns $20 \%$ para pesquisas, planejamentos, relatórios e apresentação em data shows. Hoje está com seus $100 \%$.

Em sala de aula, utilizavam para que as crianças assistissem a vídeos, ouvir músicas e para apresentar slides. Isso nos remete ao planejamento narrado pelas professoras, que é orientado por um currículo por Campos de experiências. 


\section{- Dificuldades e desafios em tempo de Pandemia}

Os relatos e registros das professoras demonstram suas afetações, travessias, desencontros com as crianças e encontros com recursos tecnológicos, principalmente os digitais. Como destacado nos fragmentos abaixo:

Isis: A falta do vínculo afetivo (eu não conheço minha turma pessoalmente pois eu estava de licença maternidade).

Liz: Falar perante a câmera não foi uma situação muito difícil pra mim, não senti vergonha e a adaptação foi tranquila, porém não estar pessoalmente com a criança, depender da familia para que tenha um bom aproveitamento do nosso trabalho, são um dos pontos mais difíceis de se adaptar.

Desencontros com as crianças na distância entre os corpos, na ausência de interações. É possível uma Educação Infantil com corpos ausentes no distanciamento do fazer e agir das crianças? As Diretrizes Curriculares Nacionais para a Educação Infantil (DCNEIs), instituiu práticas pedagógicas para e com crianças de 0 a 05 anos estruturadas em interações e brincadeira, assim, é possível currículo acontecimento, vivido e experimentado cotidianamente na ausência de corpos? As professoras apontam como uma travessia desafiadora e difícil o distanciamento das crianças, e até mesmo a impossibilidade de conhecê-las pessoalmente.

Como pensar propostas de atividades para as singularidades das crianças sem conhecê-las? 0 encontro com tecnologia digital, causando afetações de estranheza, mas de novas aprendizagens, experimentação, provocações, necessidades, condições outras de trabalho. De repente em cena outros recursos, formas outras de pensar as aulas. Mas que se desencontram das interações e brincadeiras das crianças entre pares e com as professoras.

Uma questão fomentada, são as condições de trabalho com recursos tecnológicos e Internet. Segundo Jacon et al. (2013) o professor precisa estar devidamente preparado para conduzir o processo de ensino aprendizagem utilizando as tecnologias e, as escolas equipadas adequadamente, inclusive com conexão à Internet. Outro desafio é o não acesso de algumas famílias a Internet e de equipamentos (celulares, notebooks, computador de mesa) para uso das crianças supervisionado pelo adulto, como nos seguintes relatos:

Mel: A minha maior dificuldade foi a timidez, pois não é fácil saber que todos os dias têm uma quantidade de pessoas te assistindo através dos vídeos aulas. Cheguei até fazer um cursinho para me capacitar melhor como utilizar os meios tecnológicos.

Teka: A adaptação é um processo que ainda está ocorrendo dia após dia. Ter que se reinventar de uma forma tão inesperada está sendo desafiador. Não conseguia imaginar como seriam as aulas remotas com as crianças na Educação Infantil antes de tudo isso acontecer na prática.

Os registros das experiências das professoras em um tempo que jamais pensamos viver, relatam suas afetações, suas dificuldades, desafios e encontros possíveis. Poderíamos dizer encontros mais "íntimos" com tecnologia digital atravessando suas práticas pedagógicas, por exemplo produzir vídeos. Borba (2018) aponta que "os vídeos podem ser utilizados como forma de aprendizagem e de expressão das ideias [...]". Os vídeos aparecem nos relatos como um dos recursos correntes utilizados nas práticas educativas remota em tempo de Pandemia. 
Os registros apresentam as ações das professoras em um contexto inesperado e inimaginável de viver uma Pandemia e ainda as desigualdades brasileiras de acesso a Internet, principalmente em Rondônia, que ainda convivemos com o fato de a Internet não chegar em toda sua territorialidade com a eficácia de uma Internet constante.

\section{- Planejamento das atividades}

Atualmente os relatos quanto ao planejamento das atividades em proposta remota apontam para as mudanças educativas pelo atravessamento e afetações da BNCC, como documento normatizador da Educação Básica brasileira, como observa-se nos seguintes fragmentos:

Luna: Elaboro minhas aulas com base na BNCC, e por um grupo de Whatsapp com colegas que estão lecionando com as turmas da mesma idade. Procurando ser o mais lúdico possível, com experiências, objetos concretos e alfabeto móvel, números...

Bia: Eu elaboro as aulas de acordo com os princípios da BNCC com, com os campos de experiências da BNCC como: traços sons cores e formas. O eu e o outro nós e os demais Campos de experiências.

As práticas pedagógicas apresentam uma atenção voltada aos documentos curriculares que orientam as intencionalidades educativas com crianças na Educação Infantil. Oliveira (2018, p.10) contribui ressaltando que o currículo por campos de experiências:

[...] defende a necessidade de conduzir o trabalho pedagógico na Educação Infantil por meio da organização de práticas abertas às iniciativas, desejos e formas próprias de agir da criança que, mediadas pelo professor, constituem um contexto rico de aprendizagens significativas. [...].

A organização curricular pela BNCC se estrutura em cinco campos de experiências, no âmbito dos quais são definidos os objetivos de aprendizagem e desenvolvimento, por exemplo: $\mathrm{O}$ eu, o outro e o nós; Traços, sons, cores e formas; Corpo, gestos e movimento; Espaços, tempos, quantidades, relações e transformações e Escuta, fala, pensamento e imaginação (BRASIL, 2017). Nesse sentido, como propor atividades abertas às iniciativas das crianças no atravessamento de uma Pandemia? As professoras ao planejar no encontro com a tecnologia têm encontrado caminhos outros de buscar por uma interação, relação, e garantia de práticas pedagógicas para que possam atender aos interesses das crianças, como se observa nos seguintes registros:

Bela: Elaboro as atividades em parceria com outra professora que planeja comigo, trabalhando atividades lúdicas, brincadeiras, alfabeto e números de forma divertida, com confecção de brinquedos com sucatas e massinha de modelar.

Lua: A gente elabora as aulas de uma forma que fica bem prazerosa para criança, a gente encontra tantos vídeos na Internet que fica mais fácil trabalhar online do que se estivéssemos trabalhando na escola sem nenhum recurso visual ou digital.

Teka: Tenho realizado pesquisas na Internet e troca de saberes com os demais colegas professores e procuro adaptar da forma mais prática possível para que os pais consigam realizar em casa com as crianças e com os materiais que eles possuem.

Clareto e Nascimento (2012) mencionam que "O mundo não é só o que é "dado" ou constituído, mas, fundamentalmente, aquilo que construímos e constituímos, através e a partir das relações [...]". As falas de vivências das professoras no faz refletir relações outras na ausência de corpos, nas limitações interativas, nas afetações, nos atravessamentos, nas orientações do Referencial Curricular Municipal de Rolim de Moura faz ao destacar que "Os educadores devem ter consciência da importância do seu 
papel como mediadores quanto aos direitos de desenvolvimento aprendizagem das crianças, em uma concepção, de mediar, oportunizar, organizar as experiências infantis". (ROLIM DE MOURA, 2019). O que nos provoca às seguintes indagações: quem está fazendo essa mediação com as crianças? Como é possível organizar vivências com as crianças em suas casas?

Observamos que as proposições de atividades ocorrem com uso das tecnologias, mas também com materiais concretos para que fiquem segunda os relatos das professoras "/údicas, atrativas $e$ prazerosas"às crianças. Como observa-se nas imagens:

Figura 1. Atividade de reescrita de uma receita.

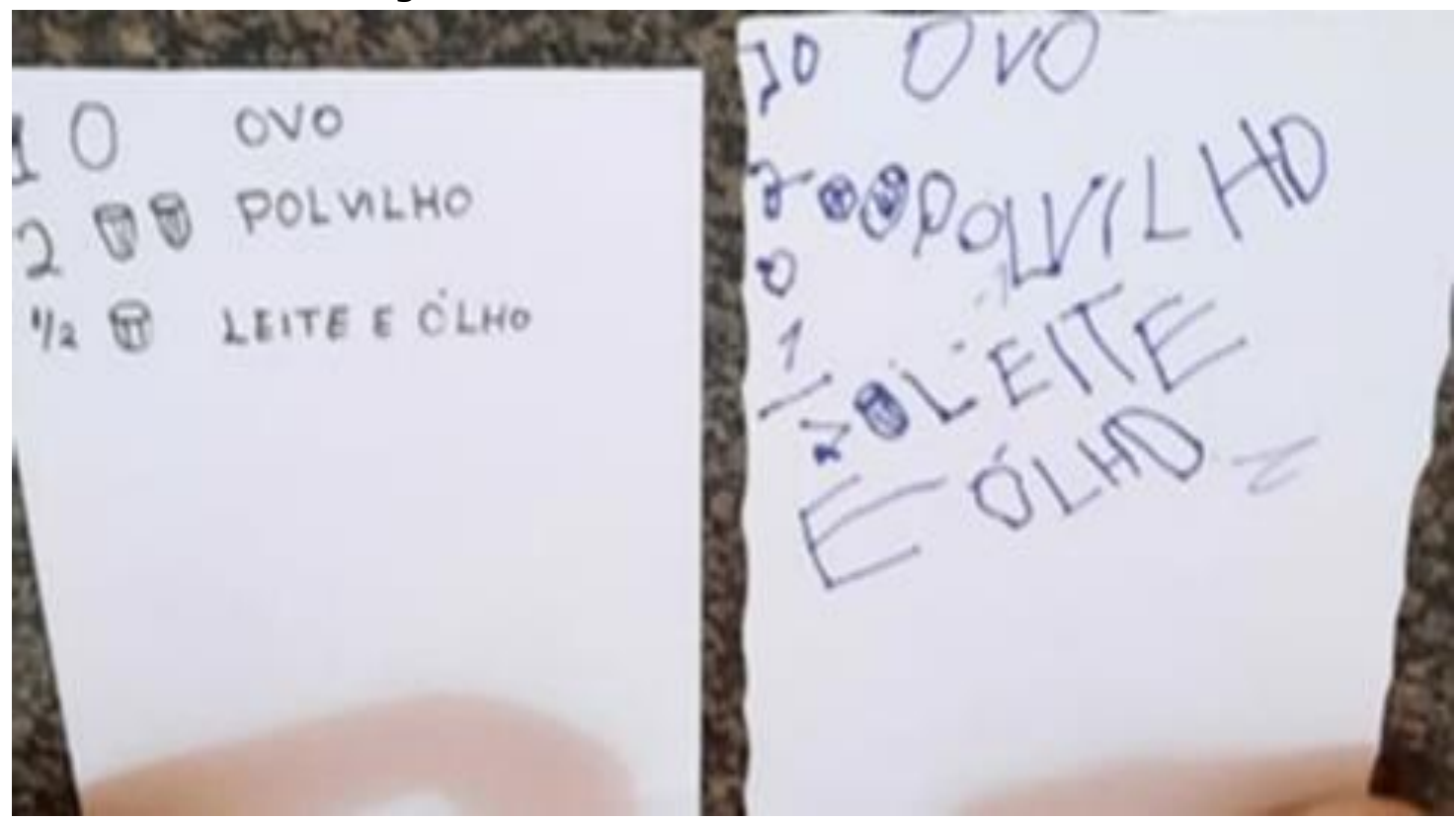

Fonte: Arquivo da professora Lua (2020).

Figura 2: Brinquedos e atividades confeccionadas pelas crianças.

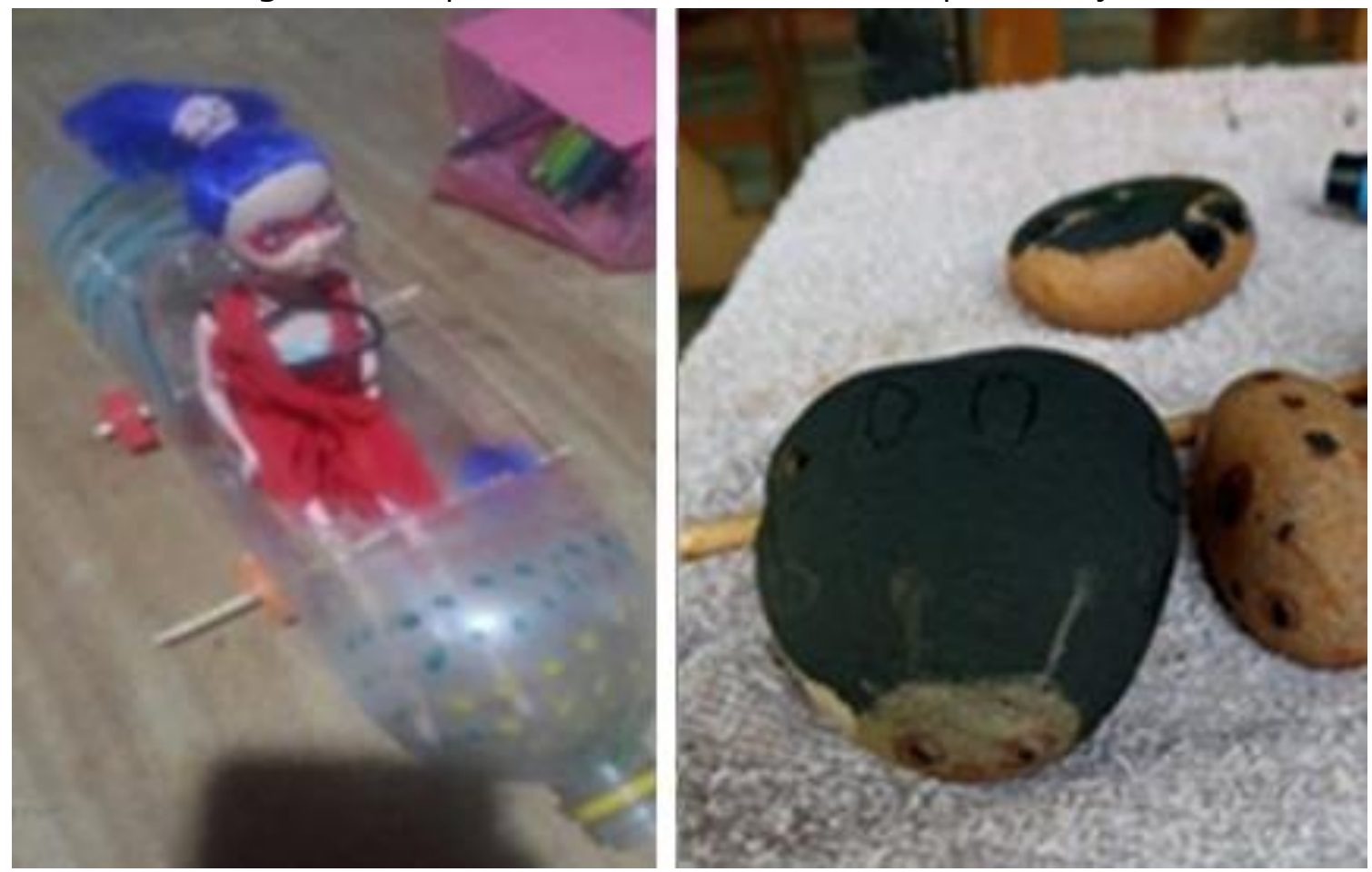

Fonte: Arquivo da professora Luna (2020). 
Figura 3: Arte feita com elementos naturais.

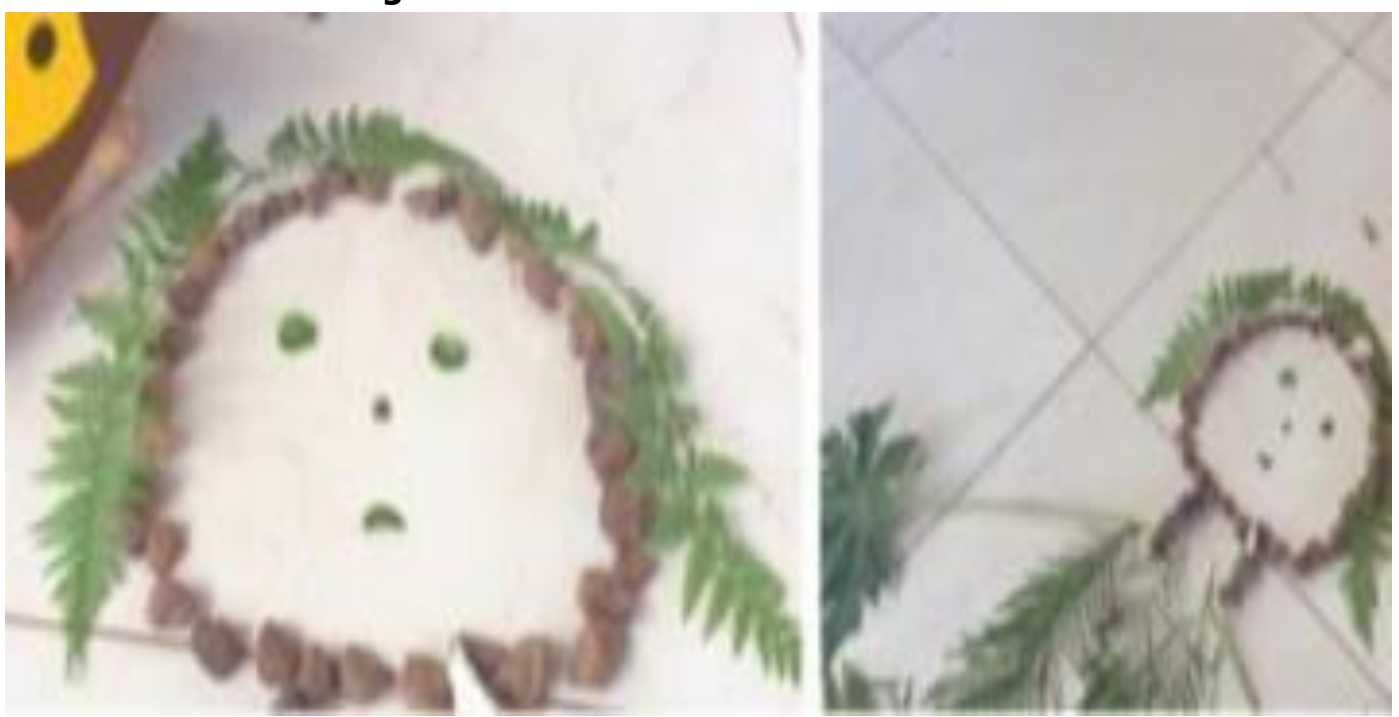

Fonte: Arquivo da professora Liz (2020).

Figura 4. Representação de quantidade utilizando feijões.

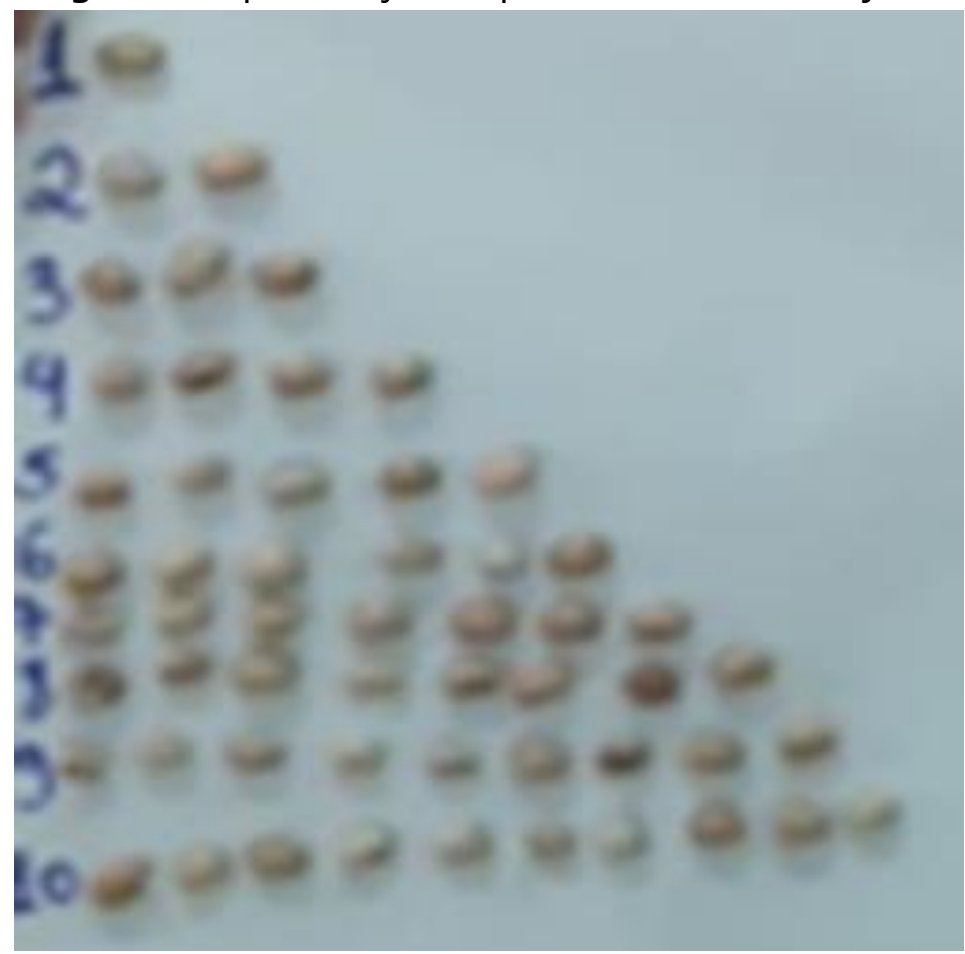

Fonte: Arquivo da professora Bela (2020).

\section{- Recursos das tecnologias de informação, comunicação e digital utilizados no desenvolvimento das atividades}

As proposições de atividades chegam às crianças e suas famílias, principalmente por meio do WhatsApp, sendo esse aplicativo o meio mais utilizado para a comunicação de instruções, orientações para que as famílias façam a mediação e apoiem as crianças em suas vivências propostas pela professora, o que antes da Pandemia era papel das docentes.

As interações virtuais via Meet foram utilizadas por 02 (duas) professoras, porém se esbarrou na dificuldade de horários compatíveis a todos, como narrado pelas participantes. Os equipamentos mais utilizados pelas professoras para o desenvolvimento das práticas pedagógicas, aparecem em destaque 
o celular e notebook, pois estão trabalhando mais em suas casas do que no ambiente escolar, como apresentados no Gráfico 1:

Gráfico 1. Como as propostas de atividades chegam até as crianças Como as propostas de atividades chegam até as crianças? (pode marcar quantas quiser) 10 respostas

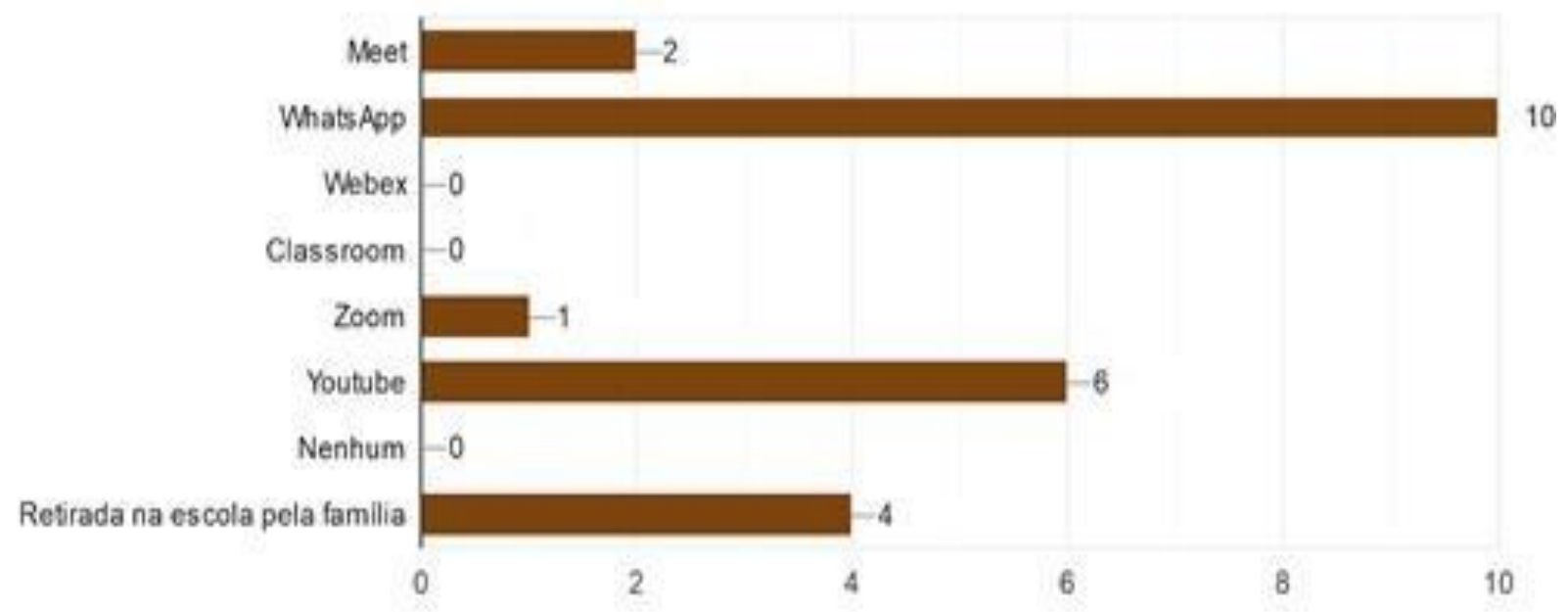

$N^{\circ}$ de protessoras

Fonte: Arquivo das autoras (2020).

Outro aspecto apresentado pelas professoras foram as ferramentas ou recursos elas utilizavam para desenvolver as propostas de atividades. Observamos que elas fazem uso de diferentes ferramentas e recursos, como expresso no Gráfico 2:

Gráfico 2: Recursos e/ou equipamentos utilizados para elaborar as práticas pedagógicas Quais recursos e/ou equipamentos você tem utilizado para elaborar suas práticas pedagógicas? (pode marcar quantas quiser)

10 respostas

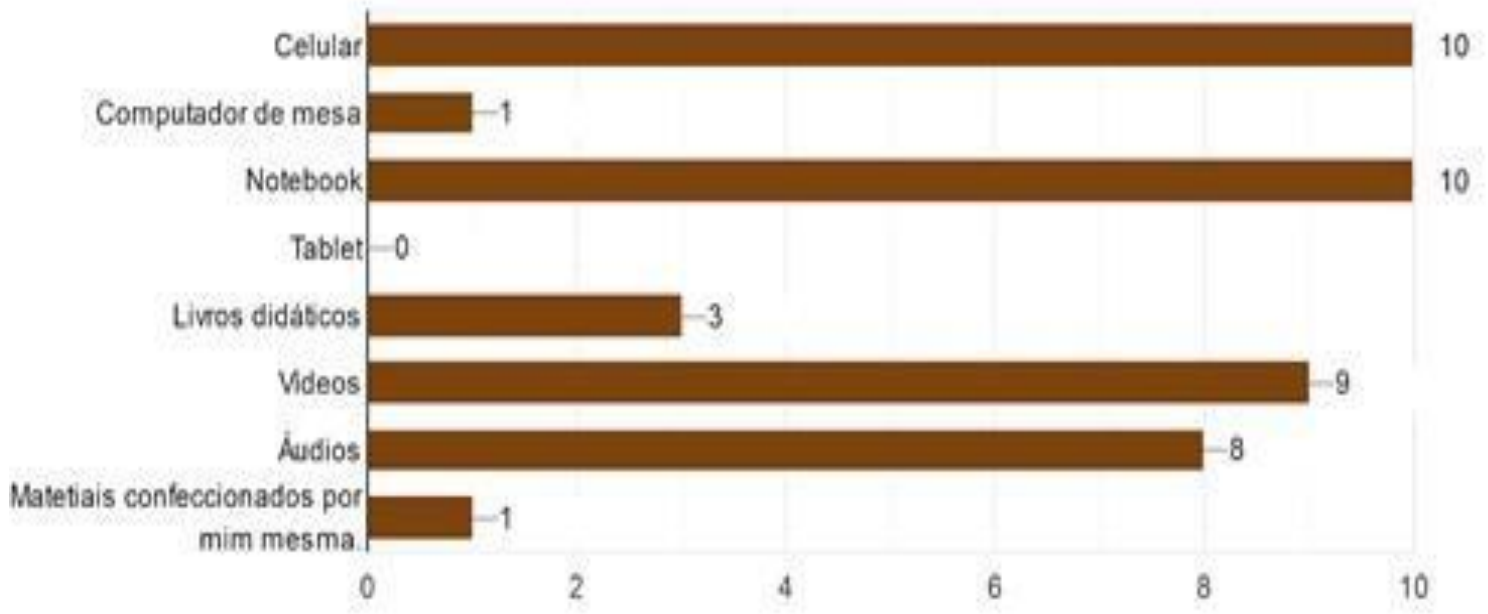

$N^{0}$ de protessoras

Fonte: Arquivo das autoras (2020). 
Abaixo temos alguns relatos deste processo que envolve as propostas de atividades e o uso de ferramentas e recursos:

Teka: O recurso que eu mais utilizo é o WhatsApp e Youtube e algumas vezes o Google Meet. Pelo YouTube eu armazeno minhas aulas e também uso vídeos de outros canais para auxiliar nas explicações. Envio minhas aulas salvas no YouTube para os pais pelo whatsapp.

Bia: Temos duas modalidades de atividades através dos vídeos enviados às famílias e para os que não tem Internet é elaborado apostiladas quinzenais.

Luna: Gravo minhas aulas e edito, porém tenho 2 alunos que não tem acesso a Internet e fiz apostila, mas senti muitas dificuldades na elaboração para sair do tradicional. $E$ devido a dificuldade de Internet e falta de energia neste mês elaborei uma apostila para toda a turma.

Flor: Os recursos que utilizo são: youtube,Whatsapp, aplicativo kinemaster, savefrom., Youtube: uso como pesquisa e complemento sobre o tema das aulas. Uso para postar as aulas no grupo dos meus alunos. E receber as devolutivas das famílias. Kinemaster: uso para editar os vídeos.

Diante desses recursos e ferramentas de comunicação e das proposições para as crianças da Educação Infantil de Rolim de Moura/RO, nos colocamos em movimento de pensar e indagar: o que pode um currículo acontecimento no distanciamento? Na ausência de interações? Segundo a BNCC:

A interação durante o brincar caracteriza o cotidiano da infância, trazendo consigo muitas aprendizagens e potenciais para o desenvolvimento integral das crianças. Ao observar as interações e a brincadeira entre as crianças e delas com os adultos, é possível identificar, por exemplo, a expressão dos afetos, a mediação das frustrações, a resolução de conflitos e a regulação das emoções (BRASIL, 2017, p. 37).

Mediante os relatos foi possível observar que as professoras buscam planejar em sintonia com os documentos que orientam as práticas pedagógicas, nas quais citam a BNCC. Porém, nos parece que suas ações são de certa forma limitadas pelo distanciamento das crianças, o que torna difícil contemplar as especificidades dessa etapa da educação básica, centralizadas nos eixos interações e brincadeira e em um arranjo curricular por campos de experiências, com propostas que considera o agir e fazer das crianças pequenas.

\section{- Como as professoras veem a utilização das tecnologias digitais na Educação Infantil}

Estes relatos são afetados e atravessados pela experiência de ser professoras na e com a primeira infância na pandemia, no distanciamento dos corpos, fora de um currículo acontecimento, refletidas nos relatos abaixo:

Bia: Com relação às tecnologias na Educação Infantil vejo que as crianças às vezes têm mais habilidades do que os adultos. Até parece que esse recurso foi feito para as crianças.

Luna: Penso que um pouco de tecnologia auxiliá no ensino aprendizagem, porém o uso demasiado se torna cansativo.

Isis: Não gosto, pois acredito que os pais não estão preparados para mediá-los da forma como eu mediária.

Liz: Vejo o uso das tecnologias na Educação Infantil como aliada para despertar a curiosidade da criança e estimular o desenvolvimento cognitivo e a linguagem, através do uso intencional e planejado tem sido benéfica para o aprendizado. 
Sol: É de suma importância pois sabendo usar facilita o desenvolvimento das aulas e no aprendizado do educando.

Bela: Na minha opinião as tecnologias ajudaram no trabalho do professor, muitas destas experiências vividas neste período de Pandemia vamos levar pra vida toda. Mas por outro lado, podemos concluir que as tecnologias jamais substituem o trabalho do professor, e na Educação Infantil as vivências diárias, o contato a socialização são primordiais para o desenvolvimento da criança.

Gallo (2019) fala de "uma infância que faz rizoma com os adultos, que se conecta com eles, perturbando suas certezas e a solidez de sua condição. A essa infância que está à margem dos adultos, mas que os atravessa na mesma medida em que é atravessada por eles [...]". As palavras de Sílvio Gallo nos fazem pensar nas experiências que se constroem nas interações entre pares e professoras, que junto à infância produzem encontros e agenciamentos, um caminhar em conjunto, um "ir junto" com as crianças, sem imposições de modelos (GALLO, 2019).

O atravessamento da pandemia que obrigou a população a viver de forma distanciada, causou o desencontro com as crianças, impossibilitou o ir junto com as crianças e possibilitou aprendizagens outras às professoras no encontro mais íntimo com as tecnologias contemporâneas, como mostra as imagens abaixo:

Figura 5. Aulas ministradas usando tecnologias digitais

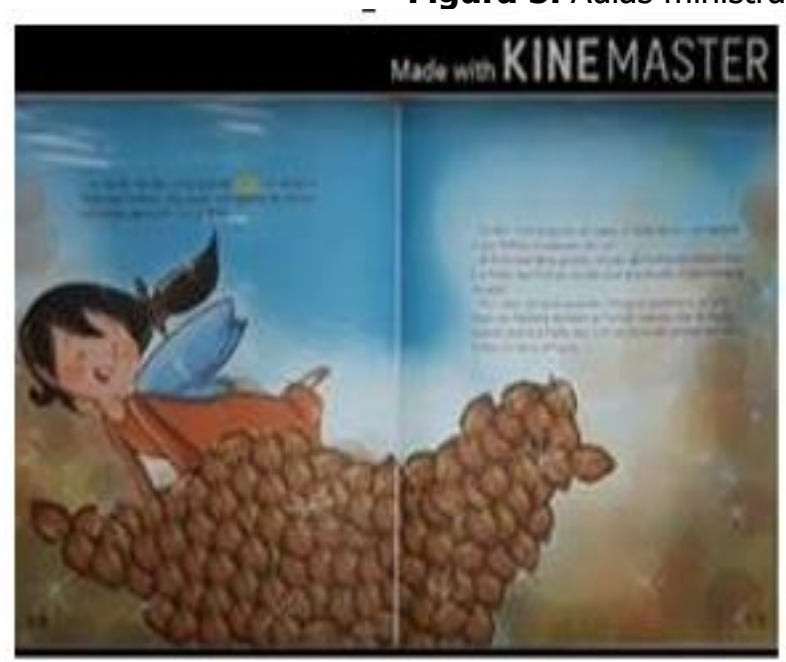

CONTAÇÄO DE HISTÓRIAS

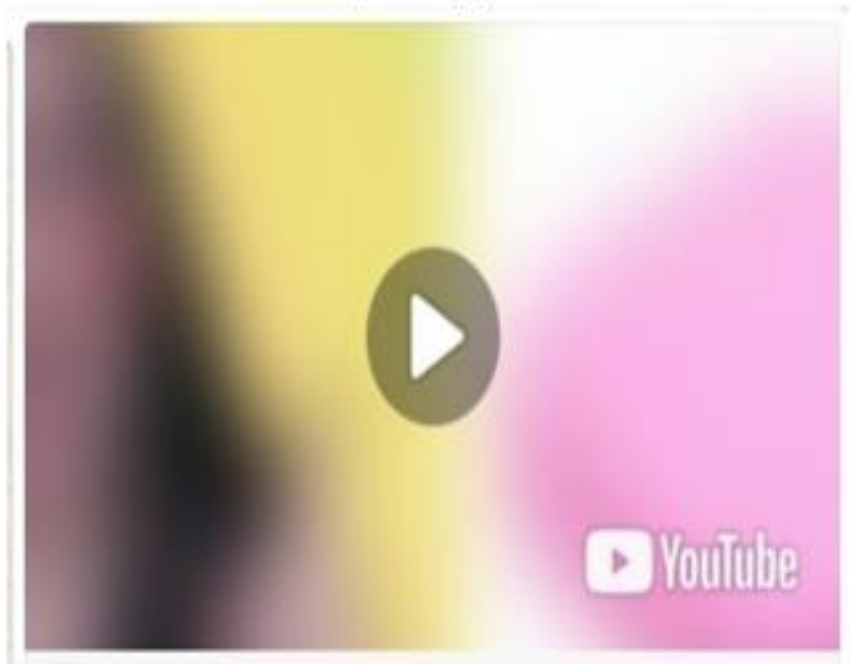

AULA MASSINHA CASEIRA 21-10-2020

Fonte: Arquivos das professoras Sol e Teka (2020).

As professoras pesquisadas apresentaram suas inquietações, seus anseios, suas inseguranças, seus desafios, dificuldades, suas necessidades e singularidades diante de um período atípico, que as colocou em movimento para fora do esperado, para fora do que até então era comum, era conhecido. $\mathrm{O}$ que nos remete às palavras de Larrosa (2002) que a experiência é "aquilo que nos passa, ou que nos toca, ou que nos acontece, e ao nos passar nos forma e nos transforma. Somente o sujeito da experiência está, portanto, aberto à sua própria transformação[...]".

Assim, as professoras ora caminhavam por caminhos conhecidos, ora sobrevoando caminhos desconhecidos e revelando através dessas narrativas seus (des)encontros, afetações e atravessamentos. 


\section{- Acompanhamento das atividades}

Quando as aulas remotas iniciaram, escola e casa se misturaram, uma invasão da escola na intimidade dos lares, as famílias mediando uma aprendizagem que antes era exclusivamente das professoras, o que pode representar neste cenário certa perda de espaço das profissionais da Educação Infantil.

Neste sentido, alguns questionamentos surgiram para refletir: até que ponto a tecnologização dialoga com a Educação Infantil? Pode a escola intrometer-se no cotidiano familiar? Pode a escola interferir na forma como se estabelecem as relações familiares? Como as crianças são afetadas pelas atividades remotas? Percebe-se nos relatos a seguir, que há uma expectativa das professoras quanto as devolutivas:

Teka: Uma questão difícil de lidar. No início as devolutivas estavam mais assíduas, porém quanto mais o tempo passa, mais percebo o distanciamento das famílias e a diminuição das devolutivas. Muita dificuldade em conciliar o trabalho com as atividades escolares são as maiores questões apresentadas por eles.

Lua: As devolutivas não são da maneira que a gente esperava, não atinge o número que a gente gostaria que atingisse.

Luna: [...] tenho tido boas devolutivas, percebo quando peço atividades relacionadas à números e alfabeto eles devolve mais, do que quando peço experiências, brincadeiras, tenho apenas 2 crianças que raramente fazem as aulas.

Bia: Nós temos ainda muito que conquistar na questão das devolutivas dos alunos, são poucos os alunos que devolvem via Internet são poucos os que estão fazendo pelo apostilado.

Neste contexto, verifica-se as expectativas das professoras da Educação Infantil, em receber um feedback das atividades para criar condições e meios de favorecer o desenvolvimento da criança em consonância com suas necessidades e interesses educacionais. A pandemia causou, e ainda causa, um emaranhado de situações que deslocam professoras e famílias de seus papéis, que modificam suas relações, que invadem seus espaços de intimidades.

\section{ALGUMAS MARCAS DAS TRAVESSIAS}

Ao observar esses relatos e registros das professoras, compreendemos as práticas pedagógicas que estão sendo oferecidas às crianças em atividades remotas, os desafios enfrentados, as afetações, os atravessamentos, os encontros e os (des)encontros enfrentados por elas. Os desafios foram impostos pela situação da Pandemia, mas percebemos que as professoras tentam propor atividades significativas às crianças.

Seus relatos demonstraram as dificuldades apresentadas por elas, principalmente ligadas a falta de intimidade com a utilização dos recursos tecnológicos digitais para fazer a mediação e chegar até as crianças. Pois, as professoras da Educação Infantil não utilizavam com frequência esses recursos em suas aulas. Outra questão colocada por elas, é que nem todas as famílias têm acesso à Internet de qualidade e equipamentos que possam disponibilizar as aulas para todas as crianças.

Neste sentido, os desafios e as dificuldades se apresentam na possível impossibilidade de serem mediadoras das crianças e na oferta de materiais possíveis de enviar as famílias. Foram obtidos relatos que nos levou a refletir: Que afetos são produzidos por uma educação que não tem o 
movimento das crianças e das professoras? Que efeitos as aulas remotas podem produzir? Como é possível um currículo acontecimento no distanciamento entre os corpos? É possível uma escola sem corpos? Espaços que não se vê... Ausência de movimentos, espaços não habitados...

Em seus relatos, as professoras apresentam a constante preocupação de propor atividades lúdicas, prazerosas e atrativas para as crianças, para garantir o possível de vivências diversificadas de acordo com os documentos orientadores das práticas pedagógicas para a Educação Infantil, dentro das limitações e condições provocadas pela Pandemia e a tecnologização das aulas remotas. Ficamos aqui com alguns outros questionamentos: o que pode uma Educação Infantil em tempos de distanciamento social? Que Educação Infantil produzir sem a interação das crianças com outras crianças? Que professora de criança nos tornamos sem estarmos juntos com elas? É possível uma Educação Infantil (escola) sem corpos? É possível conviver no mesmo espaço a casa e a escola?

\section{REFERÊNCIAS}

BRASIL. Lei de Diretrizes e Bases da educação nacional. Lei No 9.394/96, de 20 de dezembro de 1996. Disponível em: <http://portal.mec.gov.br/arquivos/pdf/ldb.pdf>. Acesso em: out. 2020.

. Ministério da Educação. Base Nacional Comum Curricular. Brasília: MEC, 2017. Disponível em:<http://basenacionalcomum.mec.gov.br/>. Acesso em: set. 2020.

Ministério da Educação. Diretrizes Curriculares Nacionais Gerais da Educação Básica. Secretaria de Educação Básica. Diretoria de Currículos e Educação Integral. Brasília: MEC, SEB, DICEI, 2013.

PORTAL MEC. Diretrizes para escolas durante a Pandemia. Disponível em:<http://portal.mec.gov.br/busca-geral/12-noticias/acoes-programas-e-projetos-

637152388/89051-cne-aprova-diretrizes-para-escolas-durante-a-Pandemia>. Acesso em: out. 2020.

Lei No 13.979, de 6 de fevereiro de 2020. Dispõe sobre as medidas para enfrentamento da emergência de saúde pública de importância internacional decorrente do coronavírus responsável pelo surto de 2019. Brasília - DF, 2020.

Decreto Legislativo № 6, de 2020. Congresso Nacional. Reconhece, para os fins do art. 65 da Lei Complementar no 101, de 4 de maio de 2000, a ocorrência do estado de calamidade pública, nos termos da solicitação do Presidente da República encaminhada por meio da Mensagem no 93, de 18 de março de 2020. Publicado no Diário Oficial da União na: Edição: 55-C, Seção: 1 - Extra, página: 1, 20 de março de 2020.

Portaria MEC No 544, DE 16 DE JUNHO DE 2020. Dispõe sobre a substituição das aulas presenciais por aulas em meios digitais, enquanto durar a situação de pandemia do novo coronavírus - Covid-19, e revoga as Portarias MEC No 343, de 17 de março de 2020, No 345, de 19 de março de 2020, e No 473, de 12 de maio de 2020. Publicado em: 17/06/2020, no Diário Oficial da União | Edição: 114 | Seção: 1 | Página: 62 Órgão: Ministério da Educação/Gabinete do Ministro. Disponível em:<https://abmes.org.br/arquivos/legislacoes/Portaria-mec-544-2020-06-16.pdf>. Acesso em: nov. 2020.

BARROS, Manoel de. O livro das ignorãças. Rio de Janeiro: Alfaguara, 2016. 
BORBA, Marcelo de Carvalho; PENTEADO, Miriam Godoy. Informática e Educação Matemática. Belo Horizonte: Autêntica 2001.

CLARETO, Sônia Maria; NASCIMENTO, Luiz Alberto Silvestre do. A sala de aula e a constituição de um currículo-invenção. Currículo sem Fronteiras, v. 12, n. 3, p. 306-321, Set/Dez 2012, ISSN 1645-1384 (online). Disponível em:< www.curriculosemfronteiras.org. >. Acesso em: out. 2020.

DELORS, Jacques et al. Learning: the creasure within. Paris: UNESCO, 1996.

GALLO, Sílvio. Educação Infantil: do dispositivo pedagógico ao "ir junto" com as crianças. In: Infância e pós-estruturalismo. Anete Abramowicz; Gabriela Tebet (Organizadoras). São Carlos: Pedro \& João Editores, 2019.

GIL, Antônio Carlos. Como elaborar projetos de pesquisa. 4. ed. - São Paulo:Atlas, 2002.

. Métodos e técnicas de pesquisa social. 6. ed. - São Paulo: Atlas, 2008.

JACON, Liliane da Silva Coelho; OLIVEIRA; Ana Carolina Garcia de; MARTINES, Elizabeth Antonia Leonel de Moraes; MELLO, Irene Cristina de. Educação \& tecnologia: reflexões sobre a incorporação de tecnologias móveis na educação. Revista REAMEC, Cuiabá - MT, n.01, setembro 2013, ISSN: Revista do Programa de Doutorado da Rede Amazônica de Educação em Ciências e Matemática. Disponível em: <http://www.ufmt.br/ufmt/unidade/index.php/secao/site/5394/ppgecem>. Acesso em: out. 2020.

LARROSA, Jorge Bondía. Notas sobre a experiência e o saber de experiência. Tradução de João Wanderley Geraldi. Revista Brasileira de Educação, No19, 20 Jan/Fev/Mar/Abr 2002.

MINAYO, Maria Cecília de Souza (org.). Pesquisa Social. Teoria, método e criatividade. $21^{\circ}$ ed. Petrópolis: Vozes, 2002.

OLIVEIRA, Zilma de Moraes Ramos de. 0 currículo na Educação Infantil: o que propõem as novas diretrizes nacionais? ANAIS DO I SEMINÁRIO NACIONAL: CURRÍCULO EM MOVIMENTO - Perspectivas Atuais. Belo Horizonte, novembro de 2010.

- Campos de experiências: efetivando direitos e aprendizagens na Educação Infantil / [Ministério da Educação]. - São Paulo: Fundação Santillana, 2018.

RIBEIRO, Ana Elisa. Termo: Tecnologia digital. In: UNIVERSIDADE FEDERAL DE MINAS GERAIS (UFMG). Faculdade de Educação (FaE). Centro de Alfabetização, Leitura e Escrita (Ceale) Departamento de Linguagem e tecnologia. Glossário Ceale: termos de alfabetização, leitura e escrita para educadores. Belo Horizonte, 2014.

ROLIM DE MOURA. Referencial Curricular Municipal da Educação Infantil. Secretaria Municipal de Educação e Cultura, 2019.

RONDÔNIA. Decreto No 24.871, de 16 de março de 2020. Decreta situação de emergência no âmbito da Saúde Pública do Estado e dispõe sobre medidas temporárias de prevenção ao contágio e enfrentamento da propagação decorrente do novo coronavírus, COVID-19, do regime de trabalho do servidor público e contratado do Poder Executivo, e dá outras providências. Diário Oficial do Estado de Rondônia n. 49, publicado em: 16 de março de 2020.

Decreto No 24.979, de 26 de abril de 2020. Dispõe sobre o Estado de Calamidade Pública, regulamenta quarentena e restrição de serviços e atividades em todo o território do Estado de Rondônia e revoga o Decreto No 24.919, de 5 de abril de 2020. Casa Civil, 26 de abril de 2020. 
Decreto № 25.263, de 30 de julho de 2020. Altera e acresce dispositivos do Decreto No 25.049 , de 14 de maio de 2020 . Art. $1^{\circ} \mathrm{O}$ parágrafo único do inciso II do art. $3^{\circ}$, o caput do art. $4^{\circ}$, o $\S 3^{\circ}$ do art. 11 e a alínea "p" do Anexo II do Decreto n. 25.049, de 14 de maio de 2020. Institui o Sistema de Distanciamento Social Controlado para fins de prevenção e de enfrentamento à epidemia causada pelo novo Coronavírus - COVID-19, no âmbito do Estado de Rondônia, reitera a declaração de Estado de Calamidade Pública em todo o território estadual e revoga o Decreto No 24.979, de 26 de abril de 2020. Casa Civil, 31 de julho de 2020.

Decreto No 25.348, de 31 de agosto de 2020. Altera, acresce e revoga dispositivos do Decreto No 25.049, de 14 de maio de 2020. "Institui o Sistema de Distanciamento Social Controlado para fins de prevenção e de enfrentamento à epidemia causada pelo novo Coronavírus - COVID19, no âmbito do Estado de Rondônia, reitera a declaração de Estado de Calamidade Pública em todo o território estadual e revoga o Decreto No 24.979, de 26 de abril de 2020, suspendendo as atividades educacionais presenciais regulares na rede estadual, municipal e privada ficam suspensas até o dia 3 de novembro do ano corrente, aplicando-se em todos os municípios. Casa Civil, 31 de agosto de 2020. 